\title{
Is Innovation Being Addressed in Entrepreneurship Undergraduate Programs? An Exploratory Study
}

\author{
Robert I. Berry, Anil Kumar, and James P. Scott \\ Central Michigan University, Mt. Pleasant, MI 48859, USA \\ Correspondence should be addressed to Robert I. Berry; berrylri@cmich.edu
}

Received 29 April 2014; Accepted 26 June 2014; Published 16 July 2014

Academic Editor: Yi-Shun Wang

Copyright (C) 2014 Robert I. Berry et al. This is an open access article distributed under the Creative Commons Attribution License, which permits unrestricted use, distribution, and reproduction in any medium, provided the original work is properly cited.

\begin{abstract}
Entrepreneurial programs have experienced a phenomenal growth in the past two decades. In this exploratory study the authors survey undergraduate entrepreneurship programs to identify courses that are being offered by these programs with the objective of determining if innovation is being addressed in the programs. The study explores innovation from both startup and corporate perspectives to see if industry needs are being met by academia. Findings suggest that entrepreneurship programs focus on functional knowledge and an opportunity exists to include courses that address innovation, design, intellectual property, and social media. Further research is needed to align market needs with academic offerings in entrepreneurship programs.
\end{abstract}

\section{Introduction}

Entrepreneurial education should be an enabling education that focuses on innovation, which we define as the creation of new capacities for wealth creation. Drucker [1] defined innovation as "the specific tool of entrepreneurs, the means by which they exploit change as an opportunity for a different business or a different service. It is capable of being presented as a discipline, capable of being learned, capable of being practiced" (page 17). We define innovation as the process of creating a product or service solution that delivers significant new customer value. Just being a new or incremental improvement by itself is not innovation unless the idea is capable of creating value or capacity for wealth creation. Entrepreneurship is the exploitation of the innovation activities. Innovation creates the potential to fuel economic growth in a nation. New products, services, or redesigned processes that result from innovation create new markets or enhance existing markets leading to economic growth. Sustaining economic growth in a nation can be challenging unless the potential to innovate is harnessed. Innovation can take place either in a startup organization or an existing organization that is well established in the marketplace (see [2, page 10]). While the number of startups created can be used to estimate innovation in startups, it is challenging to determine innovation in established organizations. Data from the Kauffman Foundation report titled Kauffman Index of Entrepreneurial Activity published in April 2013 indicates that 300 out of 100,000 adults created a new business each month in 2012 in the United States. This rate, which is a slight drop from the 2008-2011 periods, is at the same level with findings from 2007. Organizational innovation is difficult to measure as money spent by organizations on research and development may not necessarily lead to innovative solutions. Booz \& Company's findings in their annual report, The Global Innovation 1000 Study indicates, "What really matters is how those R\&D funds are invested in capabilities, talent, process and tools" [3]. If innovation is to continue, it is important that academic institutions are prepared for this challenge. Therefore, entrepreneurship programs need to provide the students with the basic business skills and an understanding of innovation in order to build the capacity for the exploitation of new business opportunities.

To address innovation needs there has been an interest in offering undergraduate entrepreneurship programs by higher education institutions. A recent report titled The Innovative and Entrepreneurial University: Higher Education, Innovation and Entrepreneurship in Focus published by the US Department of Commerce in October 2013 reports that 
there are at least 450 colleges and universities across the United States that offer entrepreneurship programs. The report also states that as a result of the Startup America Initiative more than 170 community colleges across the country have introduced entrepreneurship programs. It is evident that higher education institutions in the United States have understood the need for entrepreneurial education for fostering innovation and have adapted accordingly. Data on undergraduate entrepreneurship programs offered by schools outside the United States is not easily available. The list of Business's of Colleges with majors in entrepreneurship or small business maintained by St. Louis University John Cook School identifies 43 undergraduate entrepreneurship programs outside the United States. While it is true that undergraduate offerings in entrepreneurship have increased over the years, it is not clear whether these programs have met the innovation needs of economies and organizations. To explore the topics, this research addresses the following questions.

(1) What courses undergraduate entrepreneurship programs are offering?

(2) What is the focus of the undergraduate entrepreneurship programs, startup or corporate innovation?

(3) Are the needs of startup and corporate innovation being met by existing undergraduate entrepreneurship programs?

To answer the research questions we used the list of schools that offer undergraduate entrepreneurship as a major complied by the Saint Louis University John Cook School of Business (http://www.slu.edu/x17964.xml). This list was accessed in October 2013 and eighty-four different schools offering the entrepreneurship program major were used for this research. As shown in Figure 1 all regions of the country are included in this list and there are several international schools also.

The remainder of the paper is divided into four parts. In the next section we examine the courses that are offered by undergraduate entrepreneurship programs included in this study. The following section presents the focus of the undergraduate programs. Next the paper discusses the needs of startup and corporate innovation and if the entrepreneurship programs are meeting the needs for innovation. Finally we conclude with a discussion of innovation education in undergraduate Entrepreneurship programs with implications for future research and practice.

\section{Undergraduate Entrepreneurship Courses}

Management courses were the most common courses offered by undergraduate entrepreneurship programs followed by marketing and finance courses. As shown in Figure 2, approximately two-thirds $(67 \%)$ of the schools surveyed offered three or more management courses. While one-third (33\%) offered more than 3 or more marketing courses, approximately one-fourth (25\%) offered three or more finance courses. The data suggests that most entrepreneurship programs surveyed offer business courses that help students understand different aspects of creating and operating a
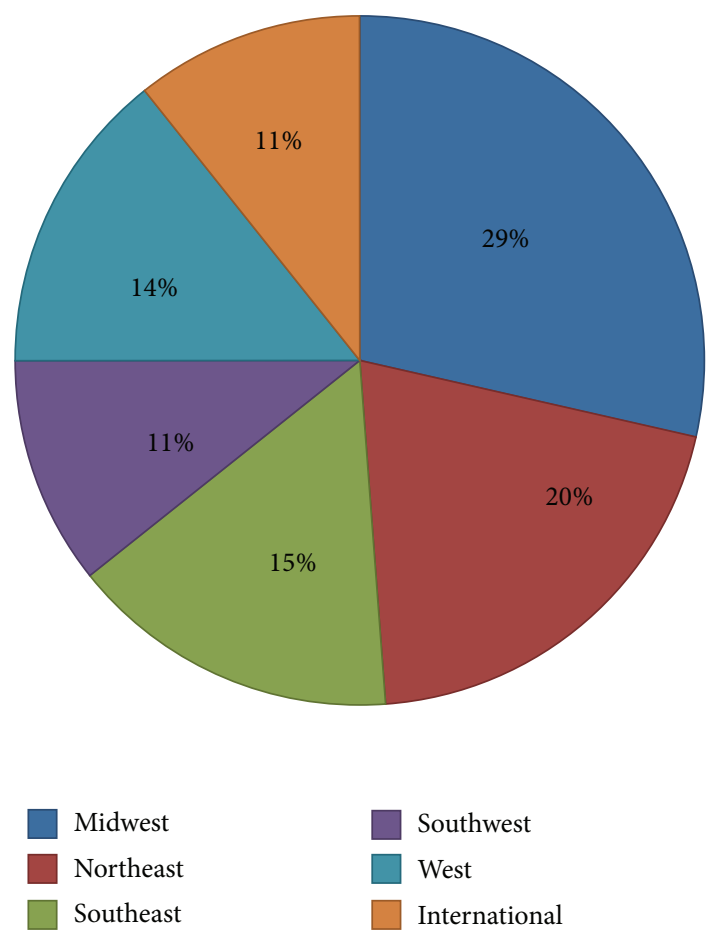

FIGURE 1: Regions represented by schools.

business. For example, the need to create a business strategy and plan may be taught in management courses, while the skills to communicate to stakeholders and make a pitch to potential investors may be taught in a marketing course. Similarly students will get the basics of funding and the financial statements that go along with funding from a finance course.

Approximately two-thirds (65\%) of the programs did not require a technology course, and $43 \%$ of the programs offered at least one technology course as an elective. Of the schools that required a technology course $46 \%$ were based in the Midwest. Technology courses as an elective were most popular in the Midwest (27\%) followed by Northeast (24\%) and the West (16\%). Technology courses generally help a student understand the transformative and disruptive potential of digital technologies. These courses also help a student develop skills that pertain to creating a digital presence.

Of the 84 programs surveyed for this study, $52 \%$ offered at least one course in innovation. Innovation courses provide the foundational theories and frameworks that help students understand how to create new products and services for the global marketplace. Entrepreneurial programs in the Midwest region (28\%) offer the most courses on innovation followed by the Northeast (23\%). A third (33\%) of the programs offered at least one course in corporate innovation. Again, the Midwest (26\%) led in offering the corporate innovation course followed by the Northeast (22\%) and Southeast (22\%). Corporate innovation helps a student understand the complexities of working with cross-functional teams in an 


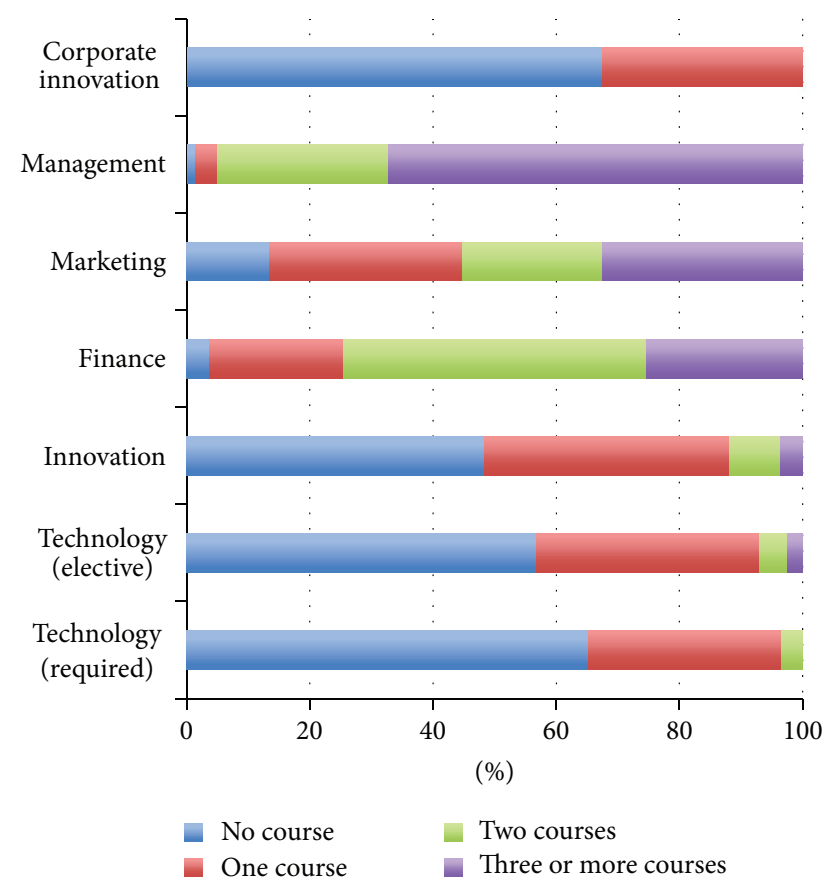

FIGURE 2: Courses offered by entrepreneurship programs.

organization to create new products and services or how to improve organizational processes.

The data suggests that entrepreneurship programs rely on a departmental approach when it comes to course offerings. Although innovation and technology courses offer the opportunity to an instructor to integrate concepts from business disciplines, most departmental courses focus on teaching business skills that emphasize functional knowledge. It is interesting to note that there were no offerings that focus on design, a critical concept for new product or service offering. Similarly courses that focus on leveraging social media for new ventures are not being offered as required courses by the programs surveyed.

\section{Focus of Entrepreneurship Education}

Innovation is critical for driving organizational growth in both startups and established organizations. While in the case of startups innovation helps introduce something completely new in the marketplace, corporate innovation requires the capability to create and acquire new knowledge that brings new ideas to the marketplace. It is clear that both startups and existing organizations need and value innovation. Entrepreneurial programs need to help students understand both perspectives and equip them with skill sets that can be used in either type of organizations.

In this study of the 84 undergraduate entrepreneur programs that we explored, approximately one-third (32\%) of the programs focused on innovation in both startup and established organizations. Slightly more than one-third (35\%) of the programs focused on startup organizations and only $1 \%$ focused on established organizations. The final third (32\%) did not focus on either, which means that their program websites do not specifically mention the focus of the program. It is quite possible that they may focus on one, either, or both but do not mention it on their website. The findings indicate that innovation in startups is more popular as a focus for undergraduate entrepreneur programs than innovation in established organizations. The focus on innovation in startups is understandable as the popular media is full of stories about new companies that emerge in the marketplace and often create a buzz that excites both faculty and students. The Western region $(24 \%)$ of US leads in terms of the programs that focus on startups followed by the Northeast (21\%) and Midwest (21\%). Technology clusters based in the Silicon Valley, Boston, and New York areas explain why programs in these regions focus on startup innovation. After the downfall of the Midwest manufacturing base it has tried to reinvent itself as a technology hub, which provides a possible explanation for the entrepreneurial programs focus on startup innovation in the region. It is surprising that corporate innovation is not the focus of entrepreneurial programs as these organizations are constantly disrupted by newcomers and have a dire need for innovation.

\section{Aligning Innovation Needs}

An organization that needs to hire human talent for innovation will rely on an individual's skills or knowledge base to assess if they are a good fit. For example, in the case of a startup organization the founding partners may be looking for creativity as a key skill. A creative individual may be able to help the founders with improving the design of a new product or service. Similarly a manager in an established organization might be more interested in someone with collaboration and teamwork skills. This helps them work with people from different functional areas to solve complex organizational problems. Entrepreneurial programs have to ensure that their course offerings help students acquire skills and build a knowledge base that are aligned with needs of the market they serve. Keierleber [4] reports findings from a Gallup-Lumina Foundation partnership study that shows that only $11 \%$ of business leaders believe that college graduates have the necessary skills and competencies to work in business organizations. An overwhelming majority (96\%) of academic leaders expressed confidence in their school's ability to prepare students for the workplace. The results from the surveys clearly highlight the misalignment that exists when it comes to perceptions about graduates' competency levels. Fischer [5] reports similar findings by pointing out that over half of the employers surveyed in a study conducted by Maguire Associates Inc., a highereducation consulting firm, on behalf of The Chronicle and American Public Media's Marketplace, struggled to find the right candidates. It is also interesting to note that in the Gallup-Lumina Foundation study findings indicate that business leaders place more importance on knowledge of field $(84 \%)$ and applied skills (79\%) than their majors (28\%) and degree (9\%). The Association of American Colleges and 
Universities in a recent report titled It Takes More than a Major: Employer Priorities for College Learning and Student Success highlights that skills rather than a student's major are more important when it comes to employability [6]. Interestingly not just the major, academic reputation [7] is also considered to be a less important factor for employers when looking for employability of graduates. So if knowledge of field and applied skills are important the question that arises is what skills are important for employers and why is there a misalignment between employer expectations and academic preparation?

Multiple academic scholars and studies have identified soft skills that include both written and verbal communications [6-8], problem solving and critical thinking $[6,7,9]$, functional skills [7], and experiential learning opportunities $[5,7,10]$, as the most important skills that employers seek when looking to hire graduates. Humphreys [6] reports that skills that help graduates innovate in their workplace are more important than all other skills. Academic leaders [11] reinforce the findings of academic studies.

From an industry perspective, multiple studies have found that innovation is critical for organizations and industries. According to the PwC 17th Annual Global CEO Survey (PwC) of more than 1,300 company leaders from 68 countries conducted in 2013, more than a third of the CEO's were looking to use their companies' ability to innovate to create new products or services to fuel organic growth with the company. The $\mathrm{PwC}$ report states, "The smartest CEOs are concentrating on breakthrough, or game-changing, innovation. They're explicitly incorporating it in their strategies. And they're using technology not just to develop new products and services, but also to create new business models, including forging complete solutions by combining related products and services. In fact, they don't think in terms of products and services so much as outcomes, because they recognize that products and services are simply a means to an end." [12]. In another study of corporate innovation conducted by the Boston Consulting Group in 2010, 1,600 senior executives put innovation near or at the top of their priority lists [13]. They reported that they have increased funding and $84 \%$ of the respondents thought that innovation was important or extremely important to their companies. It is obvious that innovation is critical for organizations though what is not clear is how effective are companies at innovation. Jaruzelski et al. [14] in their report titled The Global Innovation report that of the companies surveyed just $43 \%$ of participants said that their innovation efforts to generate new ideas were highly effective; to paraphrase the report, the companies were not very good at it. This suggests that organizations are struggling to leverage their human talent when it comes to innovation. This seems to suggest that the human talent may not have been adequately prepared for expectations of organizations when it comes to innovation. It is here that entrepreneurial programs can fill the void and support by creating programs that graduate students with the relevant knowledge base and skills that enable them to facilitate innovation in organizations.

\section{Discussion}

The need for entrepreneurship programs that help prepare students for innovation in organizations around the world is emerging due to global economic needs. Rising unemployment especially in the case of recent graduates has led to disillusionment and provides the impetus for growth of entrepreneurs around the world. Growth of government policy to promote entrepreneurship as a foundation for economic development is found at all levels of government: federal, state, and local. The development of entrepreneurship programs is not restricted to the United States but is a global phenomenon due primarily to government policies that advocate entrepreneurship as an economic development strategy. According to O'Connor [15] who developed a conceptual framework for entrepreneurship education policy, government policy makers see entrepreneurship as an economic development tool for revitalizing and stimulating economic growth. As entrepreneurs around the world continue to grow and are expected to reach 1 billion by 2020 from approximately 400 million in 2012 [16], they create endless opportunities for academic institutions. To meet the needs of the global entrepreneurs, academic institutions need to offer programs that help prepare potential entrepreneurs acquire necessary skills and knowledge base to foster innovation in entrepreneurial ecosystems around the world. Multiple factors that are interrelated and intertwined have to be taken into consideration before such programs are designed and offered to potential entrepreneurs. In the following paragraphs we discuss the focus and curriculum factors using the data from existing entrepreneurial programs presented in previous three sections. A summary of this discussion is presented in Table 1.

5.1. The Focus. We argue that all entrepreneurship programs should have a focus, that is, startup or corporate innovation that drives their program and curriculum. Schools that are not resource constrained can develop programs that focus on both startup and corporate innovation. As entrepreneurs around the world continue to drive economic activity, it is important that academic programs serve their needs. If these entrepreneurs are to succeed in their pursuits it becomes critical that academic programs support them. Support can be provided in different forms, that is, helping students create innovative products and services or a more behavioral approach where programs help students develop an innovative entrepreneurial mindset. Developing an innovative entrepreneurial mindset implies that students understand the process of generating new ideas, conducting research and development (R\&D) and testing value creation for improving processes or revamping products and services. The challenge for any program is to decide what they want to focus on.

As a first step in this process a program should make sure that they align their focus with the mission of the college and the university. Misalignment may hamper growth, as support of top administrators in the institution and academic unit may be either limited or even missing. Care must be taken to ensure that all stakeholders; that is, faculty and students (internal), the local community, and potential 
TABLE 1: Characteristics of entrepreneurship programs.

\begin{tabular}{lll}
\hline Characteristics & Startup innovation & Corporate innovation \\
\hline Focus & $\begin{array}{l}\text { Value creation by designing and creating new } \\
\text { products and services }\end{array}$ & $\begin{array}{l}\text { Value creation by improving processes, revamping } \\
\text { products and services, or conducting research and } \\
\text { development (R\&D) }\end{array}$ \\
$\begin{array}{l}\text { Curriculum } \\
\text { Experiential learning }\end{array}$ & $\begin{array}{l}\text { Technology versus design orientation coursework } \\
\text { Alignment with market needs venture competitions }\end{array}$ & $\begin{array}{l}\text { Functional versus cross-functional coursework } \\
\text { Digital versus traditional businesses }\end{array}$ \\
Skills & $\begin{array}{l}\text { Systems thinking, problem solving, critical } \\
\text { thinking, and communication }\end{array}$ & $\begin{array}{l}\text { Small and medium enterprises versus large } \\
\text { organizations }\end{array}$ \\
& & $\begin{array}{l}\text { Functional knowledge of business, team work, and } \\
\text { communication }\end{array}$ \\
\hline
\end{tabular}

employers (external) are involved in the process. Shared vision will play an important role in getting commitment of all the stakeholders as they will view it as their personal vision [17]. Internal stakeholders impact what happens in the classroom and external stakeholders ensure that necessary support can be provided to create a thriving entrepreneurial ecosystem. Though the focus may be local to address the needs of external stakeholders, global perspective should not be ignored. For example, if a program decides to focus on startup innovation in general and digital entrepreneurship in particular, the potential for online businesses to reach global markets becomes important.

5.2. The Curriculum. Not all courses are equally useful and the focus of the program should determine the courses that are important for the program. As the data suggests, entrepreneurship programs focus on courses that help students achieve functional specialization. Although we did not collect any data, it is likely that courses may be crosslisted in different departments. For example, if a course is cross-listed as a management and entrepreneurship course then it becomes very difficult to design the course for an entrepreneurship student, as needs of management students cannot be ignored completely. There are management theories and concepts that students from both disciplines need to know even though the perspective varies. Similarly, a course in information systems (IS) can be taught in the IS and entrepreneurship disciplines; however, the viewpoint in the two disciplines can be different. We believe that the focus of an entrepreneurship program should drive the curriculum in the program. Courses that help emphasize functional knowledge should be combined with courses that transcend functional boundaries and help students understand the big picture. This implies that core courses in entrepreneurship programs may differ driven by the focus of the program.

A program that focuses on startup innovation needs to decide what aspect of startup innovation is of interest to the school. For example, is the program focused on startup innovation from the perspective of solving local community economic or social problems or is it technological innovation in general? In the former case, courses that help students understand setting up small businesses in local communities become more important, while in the latter case the emphasis can be on technology courses. Needs of setting up small businesses differ from needs of a technological business and these needs should drive the coursework in the program. If the startup is creating an innovative product or service then design is critical. It can be argued that most business courses do not focus on design. A program should consider including design courses that may or may not be offered by the department. Similarly when designing a new product or service it is important that students understand the concept of intellectual property and how to protect it. The process of searching and applying for patents are time and financial consuming activities and students need to understand its significance. Courses that focus on design intellectual property become relevant and important for an entrepreneurship program and should be included depending on the focus of the program.

Entrepreneurship programs that focus on corporate innovation need to take a systems thinking view that concentrates on putting in place a disciplined innovation strategy when designing their programs. As mentioned in earlier paragraphs functional knowledge is important, though equally important is the understanding that innovation in organizations happens when organizational boundaries are crossed and existing mental models are ignored. This can be achieved in academic settings when courses are specifically designed to help students understand cross-functional problem solving. Faculties from different disciplines need to participate in designing such courses and academic unit leaders need to provide support to these faculties. Often resource constraints and promotion and tenure requirements limit involvement of faculty from different disciplines in such endeavors. Formal and informal communication systems can be created to support faculty and students as they attempt to create innovative solutions to organizational problems or exploit opportunities. Emerging technologies such as social media tools should be harnessed to enable faculty and students to work in teams or individually.

Experiential learning should be mandatory for all entrepreneurship program students to understand innovation. Entrepreneurship programs either require their students to intern in organizations or provide competitive platforms such as new venture competitions where students can compete for seed money to support their entrepreneurial ventures. Both are good experiential learning opportunities for students, although it may not be adequate for aspiring entrepreneurs. Many entrepreneurs that have succeeded have 
experienced multiple failures over the years. Unfortunately the media stories center around their successes and often ignore their failures. Failure can be a practical learning tool for students. It is the multiple failures and the failure analysis that students need to experience before they graduate from an entrepreneurship program. Every student in an entrepreneurship program should be required to build or create an innovative product or service. Once a student has created something they should present it to their peers and faculty to get feedback. The local business community should also be involved in this process in order to provide feedback and analysis of the student's efforts. The emphasis should be on providing students the opportunity to fail fast and fail often during their program so that they understand the path traversed by entrepreneurs. It is equally important that students enrolled in entrepreneurship programs are provided the opportunity to learn from the failures and mistakes of students that graduated from the program. Either inviting alums as guest speakers or offering a special topics course on failures and mistakes can accomplish this. Over the years programs can create a database of lessons learnt from failures and mistakes, which can become the content for a course that addresses this topic.

\subsection{Aligning Focus and Curriculum to Market Needs. Data} presented in the previous section clearly indicates that CEOs consider innovation to be critical for sustaining corporate success and they feel that college graduates are not prepared adequately to work in the real world. Specifically graduates were seen lacking knowledge of field and applied skills that help them become marketable. If graduates do not have sufficient field knowledge, an understanding of digital technologies, and applied skills, then innovation in corporate organizations may be difficult to achieve. Similarly if one were to view the startup landscape it is important that graduates of entrepreneurship programs possess skills that help them build or create startups. Based on the data on focus of entrepreneurship programs and courses offered (see Figure 3), it is evident that an opportunity exists for programs to adapt their offerings for aligning with market needs . For example, even though one-third of the schools surveyed focused on startup innovation the courses offered focus on functional knowledge. A focus on startup innovation calls for preparing students with skills that have them build a startup. Functional knowledge is very important; even for a startup you first need to create something. It is only when you create something that you have to think about management or finance. Creating or building a startup necessitates that students can identify problems in society, view problems from multiple perspectives, and then brainstorm with their peers, faculty and community to find potential solutions to problems. Skills that become critical in this scenario are systems thinking, problem solving, critical thinking, and communication. While courses focusing on functional knowledge may address these skills, it is not the focus of the course. We did not collect data on the number of

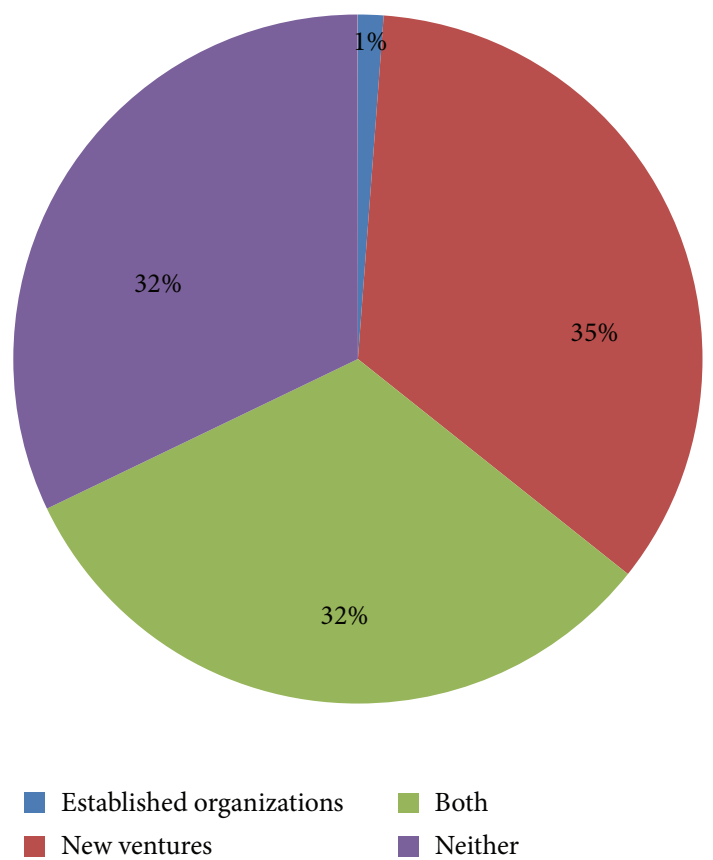

FIGURE 3: Focus of entrepreneurship programs.

innovative startups from the schools surveyed, but we believe the number will be very low.

To align market needs with the focus of the entrepreneurship program and coursework we recommend that a school first consider the ecosystem that it is a part of. If a school is located in a geographic region where there is limited access to large corporations that provide potential employment opportunities for graduates, then the school needs to view alignment from the perspective of creating an entrepreneurial ecosystem that focuses on startup innovation. The focus on startup innovation can then be viewed from two different aspects, small business startups or technology startups. While small business startups can be helpful to build businesses that meet local needs or solve economic problems that the community faces, technology startups provide an opportunity for students to become a part of the global network of entrepreneurs leveraging technology. It is important for the school to assess their resources and capabilities to ensure that students are provided the opportunities to create innovative startups.

\section{Conclusion}

Entrepreneurship programs provide an opportunity for academic institutions to graduate students that can contribute in meaningful ways to solve complex societal and organizational problems. The knowledge base and skill set needed for innovative solutions to societal and organizational problems requires a unique mindset for designing an entrepreneurship program. Entrepreneurship programs that focus on creating an entrepreneurship ecosystem aligned with market needs and taking into consideration the resources and capabilities available will graduate students that are in demand. The 
entrepreneurship ecosystems can be viewed from either a startup or corporate innovation perspective. In this research we provide recommendations and suggestions for the knowledge base and skill set that must be considered when designing entrepreneurship programs. These recommendations are based on an exploratory review of existing entrepreneurship programs. We understand that the data used for the study limits generalizability but it provides a foundation for future research. We recommend that future studies expand the dataset of entrepreneurship programs especially from outside the United States and test if our recommendations are meaningful.

\section{Conflict of Interests}

The authors declare that there is no conflict of interests regarding the publication of this paper.

\section{References}

[1] P. Drucker, Innovation and Entrepreneurship, Elsevier, Butterworth-Heinemann, Burlington, Mass, USA, 2007, Classic Collection.

[2] D. O'Sullivan and L. Dooley, Applying Innovation, Sage Publications, Thousand Oaks, Calif, USA, 2009.

[3] B. Jaruzelski, J. Loehr, and R. Holman, "The 2013 Global Innovation 1000 Study: Navigating the Digital Future," 2013, http://www.booz.com/global/home/what-we-think/reportswhite-papers/article-display/2013-global-innovation-1000study.

[4] M. Keierleber, "Business and academic leaders disagree on quality of college graduates, surveys find," The Chronicle of Higher Education, no. 25, article A15, 2014.

[5] K. Fischer, "A college degree sorts job applicants, but employers wish it meant more," The Chronicle of Higher Education, 2014, https://chronicle.com/article/The-EmploymentMismatch/137625/\#id=overview.

[6] D. Humphreys, "Employers More Interested in Critical Thinking and Problem Solving Than College Major," 2014, http://www.aacu.org/press_room/press_releases/2013/ leapcompactandemployersurvey.cfm.

[7] D. J. Finch, L. K. Hamilton, R. Baldwin, and M. Zehner, "An exploratory study of factors affecting undergraduate employability," Education and Training, vol. 55, no. 7, pp. 681-704, 2013.

[8] T. Chamorro-Premuzic, A. Arteche, A. J. Bremner, C. Greven, and A. Furnham, "Soft skills in higher education: importance and improvement ratings as a function of individual differences and academic performance," Educational Psychology, vol. 30, no. 2, pp. 221-241, 2010.

[9] J. R. Reid and P. R. Anderson, "Critical thinking in the business classroom," Journal of Education for Business, vol. 87, no. 1, pp. 52-59, 2012.

[10] J. Gault, J. Redington, and T. Schlager, “The benefits of undergraduate business internships: implications for the student, university, and business community," Journal of Marketing Education, vol. 22, no. 1, pp. 45-53, 2000.

[11] J. Jiambalvo, "Dean's Corner: How Entrepreneurship Programs Help Students Meet the Needs of Corporate Recruiters," 2013, http://enewsline.aacsb.edu/deanscorner/jiambalvo.asp.
[12] P. Cheah, A. Lang, S. Snowden, and S. Watts, "PwC 17th Annual Global CEO Survey," 2014, http://www.pwc.com/ gx/en/ceo-survey/index.jhtml?WT.ac=vt-ceosurvey.

[13] S. David and R. Dreischmeier, "(Technology-Enabled) Innovation: A Weapon to Win the Battle for Competitive Advantage," The Boston Consulting Group, 2010, https:// http://www.bcg.com/documents/file50205.pdf.

[14] B. Jaruzelski, J. Loehr, and R. Holman, The Global Innovation 1000: Making Ideas Work, No. 69, Strategy+Business Magazine, 2012.

[15] A. O'Connor, "A conceptual framework for entrepreneurship education policy: meeting government and economic purposes," Journal of Business Venturing, vol. 28, no. 4, pp. 546-563, 2013.

[16] A. Vital and V. Shyshov, "The next billion-women entrepre-neurs," 2014, http://fundersandfounders.com/the-nextbillion-women-entrepreneurs/.

[17] P. Senge, The Fifth Discipline: The Art and Practice of the Learning Organization, Doubleday/Currency, New York, NY, USA, 1990. 

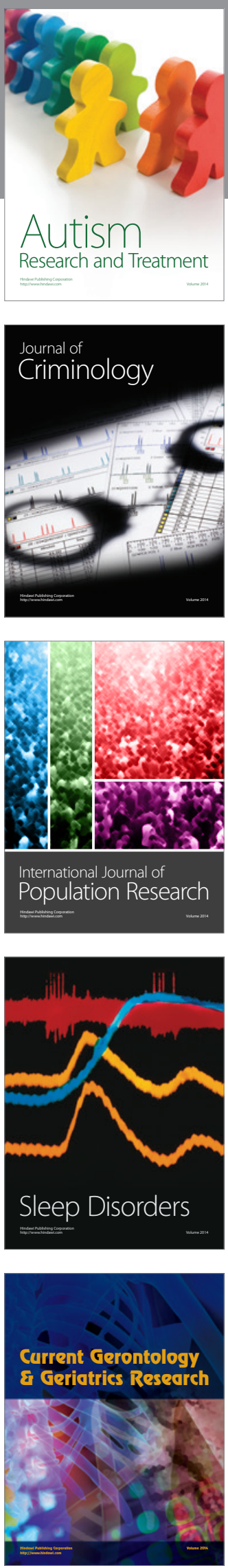
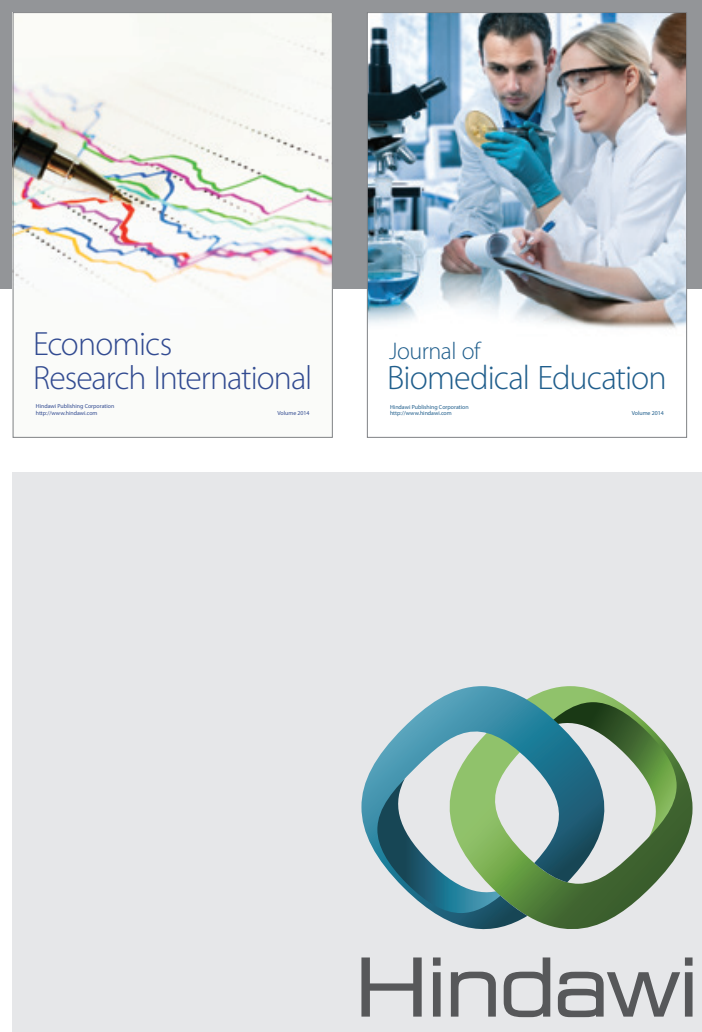

Submit your manuscripts at

http://www.hindawi.com
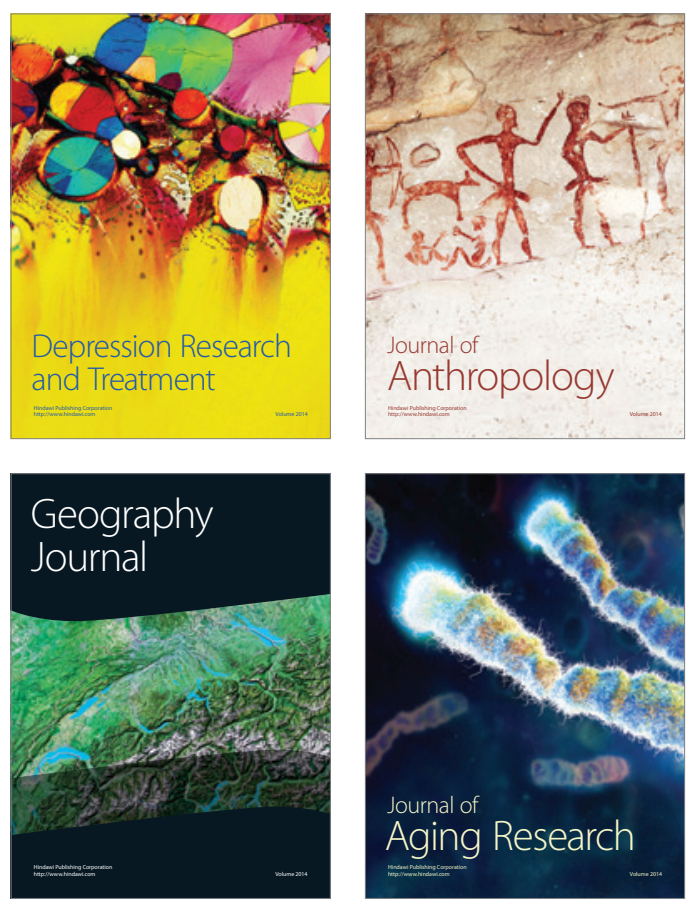
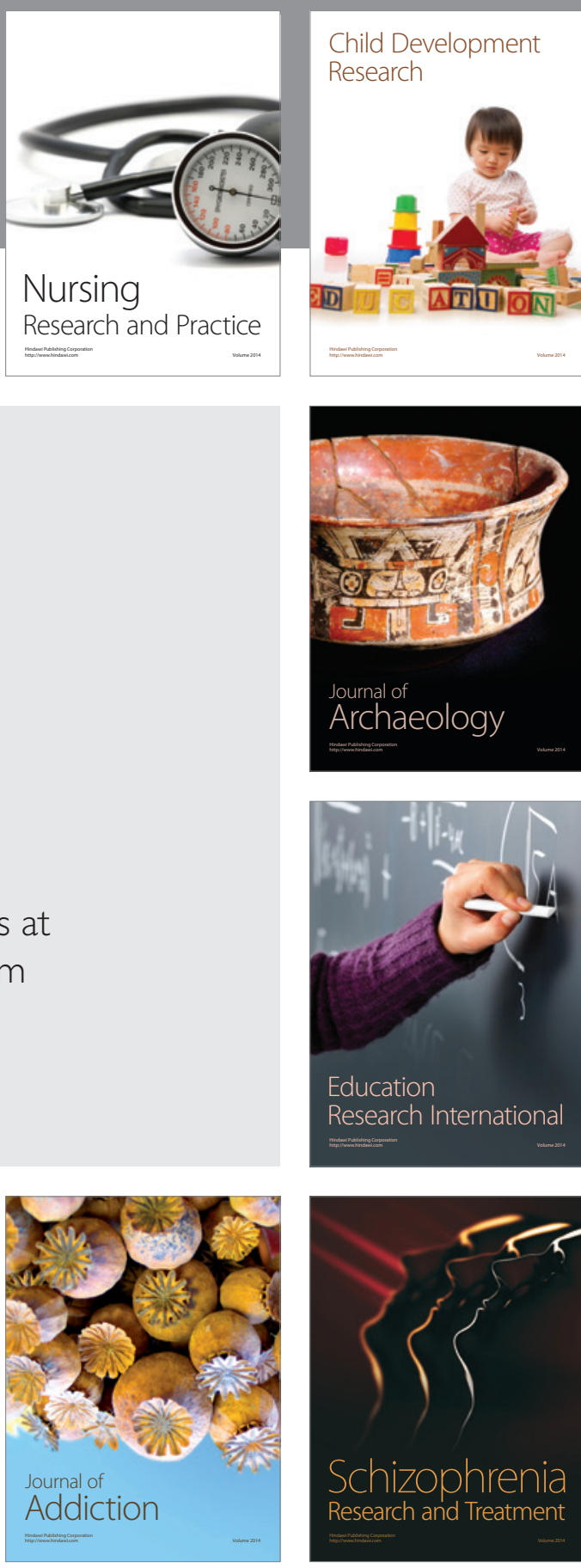

(D)
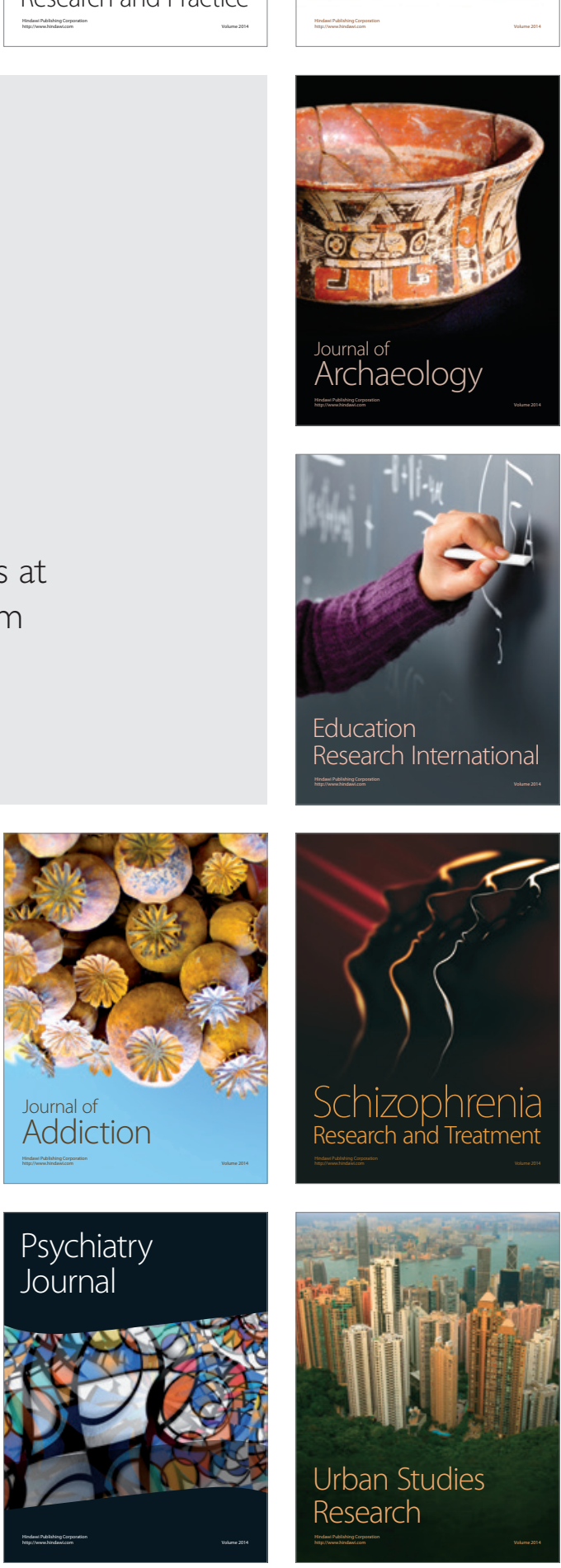